
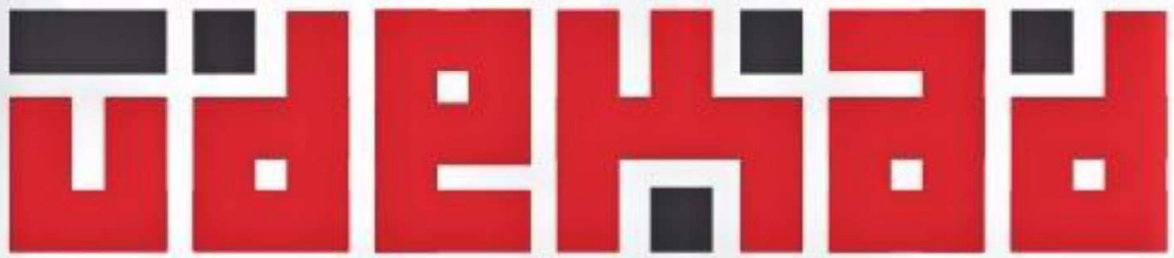

INTERNATIONAL JOURNAL OF LANGUAGE, LITERATURE AND CULTURE RESEARCHES

МЕЖДУНАРОДНЫЙ ЖУРНАЛ ЛИНГВИСТИЧЕСКИХ, ЛИТЕРАТУРОВЕПЧЕСКИХ И КУЛЬТУРОЛОГИЧЕСКИХ ИССЛЕЛОВАНИЙ

Vol: 2, Issue: 2, 2019

Sayfa-Page: $80-90$

E-ISSN: 2667-4262

\title{
ALBERT CAMUS'NUN ABSÜRD KAVRAMI IŞIĞINDA INSANIN YAŞAM VE ÖLÜMDE ANLAM ARAYIŞI
}
ALBERT CAMUS' IN THE CONTEXT OF ABSURD CONCEPT HUMAN SEARCHING OF MEANING IN LIFE AND DEATH

\section{Özgün Zülal şìMŞEK*}

\begin{tabular}{|c|c|}
\hline MAKALE BİLGİSİ & ÖZET \\
\hline $\begin{array}{l}\text { Gelis: } \\
\text { Kabul: }\end{array}$ & \multirow{3}{*}{$\begin{array}{l}\text { Niçin var olduğumuzun ya da ne için hayatta bulunduğumuzun mutlak bilgisine sahip } \\
\text { değiliz. Dolayısıyla her insanın, yaşamının en az bir anında hayatın anlamını, yaşamı ya da } \\
\text { ölümü sorgulamış olması muhtemeldir. İnsan niçin yaşar? Ya da insan niçin intihar eder? } \\
\text { Hayatın aniden sona ereceğini düşündüğümüz için mi hayatımızda bir anlam arıyoruz? Bu } \\
\text { ve benzeri sorular } 20 \text {. yüzyılın öne çıan isimlerinden biri olan Albert Camus'nun de } \\
\text { aklından geçmiş olacak ki intihar kavramına dikkat çekmiştir. Hayatın anlamını ve } \\
\text { yaşanmaya değer olup olmadığı hakkında bir yargıya varmayı esas ve öncelikli felsefi } \\
\text { problem olarak görmüştür. Camus insanın, yaşadığ dünyaya ve kendine yabancılaşmasıyla } \\
\text { ortaya çıkan absürd durumu incelemiş ve buna tanrısal bir varlığa bağlanmayan bir tavırla } \\
\text { yaklaşmışıtır. Bu çalışmanın amacı Albert Camus felsefesi ışığında yaşama dair bir anlam } \\
\text { arayışı, ölüm, intihar ve absürd kavramlarına odaklanmak olacaktır. Onun felsefi çatısı } \\
\text { altında hayatın yaşanmaya değer bir olgu olup olmadığı, karamsarlığın, zorluğun, } \\
\text { umutsuzluğun hatta acının hüküm sürdüğü bu dünyada yaşamın mutlak bir değer taşıyıp } \\
\text { taşımadığı hususuna değinilmeye çalışılacaktır. }\end{array}$} \\
\hline $\begin{array}{l}\text { Anahtar Kelimeler: } \\
\text { Yaşamın Anlamı, } \\
\text { Absürd, } \\
\text { Intihar, } \\
\text { Ölüm, } \\
\text { Umut. }\end{array}$ & \\
\hline Araştırma Makalesi & \\
\hline
\end{tabular}

Received: 10.11 .2019

We do not have an absolute knowledge of why are we exist or what are we living for. Therefore, it is possible that every human being has queryed the meaning of life, living or death at least one time on his life. Why do people live? Or why do people commit suicide?

Accepted: 12.10 .2019 Are we looking for meaning in our lives because we think life will end suddenly? These questions and similars must have come into the mind of one of the prominent names of the 20th century, Albert Camus. Because he draws attention to the concept of suicide as the only and priority problem of philosophy. He considered to make a judgment as to whether life is worth living and the meaning of live as a fundamental and philosophical problem. Camus researched the absurd state that occurs when man is alienated from the world he lives in with Incompatible and he approached it in an attitude which is independent from divine being. The purpose of this study is to focus to death suicide, quest about meaning of life and absurd concepts in the light of Albert Camus' philosophy. It will be tried to point out whether life is an event that is worth living, whether the life has an absolute value in this world where pessimism, difficulty, despair and even pain prevail with his philosphy.

Research Article

* Yüksek lisans öğrencisi, Ankara Yıldırım Beyazıt Üniversitesi, Felsefe Bölümü, Ankara / Türkiye, E-mail: zulallozgun@gmail.com.

ORCID (D) https://orcid.org/ 0000-0002-0753-780X.

Bu makaleyi şu şekilde kaynak gösterebilirsiniz (APA):

Şimşek, Özgün Zülal (2019). "Albert Camus'nun Absürd Kavramı Ișığında İnsanın Yaşam ve Ölümde Anlam Arayışı".

Uluslararası Dil, Edebiyat ve Kültür Araştırmaları Dergisi (UDEKAD), 2 (2): 80-90. 


\section{Extended Abstract}

The aim of this study is to make an inquiry about the meaning of life and death concepts based on Albert Camus philosophy. Discordant and revolt is forms the cult concepts of Camus philosophy. His philosophical thought is to try to reach the consciousness of discordant. Camus saw the solution in the struggle against the discordant in rebellion. The phenomenon of death is the basic idea in the emergence of these two concepts.

The method of the study was to examine the subject by making explanations from Albert Camus philosophy and works. In the first part of the article, an introduction to the philosophy of Camus is made and the subject is outlined. Albert Camus saw whether life was worth living or not, as the most important philosophical problem. In many of his works, he has dealt with how people become alienated from themselves, society and the world. There are many quotes in this article. According to Albert Camus, people fell into a world who did not know the meaning of. Therefore, it develops various questions to understand this situation. However, his inability to find an answer to existential questions with reason begins to isolate him from society and the world. Because in human existential questions, mind is insufficient. According to Camus' definiton, discordant is the fact that people cannot understand the World through reason, even though he is the existence of reason. There are two options to eliminate people's discordant. These are hope and suicide. Albert Camus, however, strongly opposes both options. According to Camus, hope is to desire another life. Suicide eliminates the discordant but destroys the person. For this reason, Camus refuses to commit suicide. So hoping to eliminate discordant or suicide is not a solution. One can only stand against the discordant by accepting its existence. The subject integrity of the first part of the article is thus formed.

The section titled "Discordant", focuses on the content of the concept. This section describes Camus's incompatible problem and the solution it has developed for it. According to Albert Camus, discordant does not only represent one person. Discordant describes the lack of communication between people and the world. Human beings are curious, questioning and conscious. Therefore, he tends to understand his life. However, this orientation remains unrequited. The discordant in here is not just a person or a world. Discordant consists of a disconnect between human consciousness and the world. This situation will continue as long as the world and people exist. Therefore, Camus develops a rebellion philosophy to eliminate discordant. He examined the discordant situation that emerges from the alienation of people and himself to the world by a method that cannot be connected to the divine being. He said that people has to do to get rid of this cordant is rebellion. This point has been criticized in the article. Discordant is a fact of life and we have no choice but to accept it. So choosing to live against nonsense means rebelling against it.

Camus, who opposes suicide with a certain language, interprets it as an escape. According to him, what is difficult is to live, suicide is an easy way. Although it is difficult, it is worth living to struggle. Because he argues that choosing to die is not understanding life. Since it is not possible to escape from discordant, choosing life means giving it a value. Therefore, what makes life meaning is rebellion. These issues are explained in the "Suicide" section of the article.

As a result of the study, the importance of the concept of hope in human life was emphasized. Camus's hope has been criticized for a negative meaning. The article gave up everything and concluded that hope is the only thing that can connect a person who wants to end pain. Main theme of the article is that peole must hope to endure the cruelty of life. 


\section{Yaşama Karşılık Ölüm}

İnsan ne için yaşar? Yahut yaşamayı kendi iradesiyle seçmemiş, bir deyişle adeta dünyaya firlatılmış olan insan, niçin yaşamaya devam eder? Budistler, putperestler, Hristiyanlar veya ateistler... İnsan niçin kendi seçmediği bir yaşama evet der? Eğer iyi, orta ya da idare eder standartta bir hayat düzenine sahipseniz yaşamayı seçmek makul görülebilir. Peki, acılar içinde umutsuzluk, karamsarlık, yokluk, açlık, korku, kaygı, endişe, hastalıklar ve işkencelerle dolu çaresiz bir hayat savaşının ortasında kalıp da, insan yaşamayı niçin sürdürür? Tüm bunlar öznel cevaplardan öteye geçemeyen büyük bir gizem. Bütün insanlarla birlikte filozofların da cevap aradığı, bu ve benzerini getiren sorular bizi Camus'un da sormuş olduğu hayatın yaşanmaya değer olup olmadığı konusunda bir karara varmaya zorluyor.

İnsan hayatında, evrensel bir gerçekliğe sahip olan ölüm düşüncesi, tüm sarsıcıllğı ve yıkıcılığına rağmen her canlının er ya da geç yaşamda ulaşacağı kaçınılmaz sondur. Muhakeme yeteneğine sahip her insanın zihnini meşgul eden bir kavram olan ölüm, yaşamın temel güdüsünü ve dinamiğini içinde barındıran bir niteliğe sahiptir. Her ne kadar insan, öleceğini bilmesine rağmen ölüm kendisine hiç uğramayacakmış gibi bir ironide yaşasa da ölüm, yaşamın bir doğal getirisidir. Yaşam aslında ölüme giden serüvendir, ölmek için yaşamak gerekmektedir.

İnsanın, içinde bulunduğu dünyaya akıl yoluyla yaklaşması ve bazı sorularına dünyada bir cevap bulamayışı onun hayata ve yaşam habitatına yabancılaşmasına sebep olur. $\mathrm{Bu}$ noktada insan farkında olmaya ve sorgulamaya başlar. Hepimizin belli yaşlarda belli zamanlarda hayatın anlamını sorguladığımız olmuştur. Camus bunu şu sözlerle ifade eder: "dekorların yıkıldığı olur. Yataktan kalkma, tramvay, dört saat çalışma, yemek, uyku ve aynı uyum içinde sall, çarşamba, perşembe, cuma, cumartesi çoğu kez kolaylıkla izlenir bu yol. Yalnız bir gün 'neden?' yükselir ve her şey bu şaşkınlık kokan bıkkınlık içinde başlar', (Camus 2016: 31). İnsan, tüm bu olup bitenlerin neden olduğunu merak eder ve onu bilmek ister. Çünkü insan, tarih boyunca merakına yenik düşerek bilinmez olanı bilme arzusunda çabalayıp durmuştur.

Yabancı adlı romanının başkahramanı Meursault'a şunları düşündürür Camus: " $B u$ hayat bana ait değildi ama en küçük ve en güçlü mutluluklarımı; sevdiğim mahalleyi, gökyüzünün akşamları aldığı her çeşit hali, Marie'nin gülüşlerini ve giysilerini o hayatta bulmuştum ben. Burada oluşumun lüzumsuzluğu birdenbire canıma tak etti" (Camus 2016: 95).

Camus eserlerinde pek çok kez insanın kendine, dünyaya ve diğer insanlara karşı nasıl yabancılaştığını anlatmıştır. İnsanın kendi algısında ve toplum karşısında kim oluğuna dair kesin bilgisinin olmaması bireyi kendi içinde yabancılaştırarak toplum içinde de ötekileşmesine sebep olmuştur. Kişi yabancılaşmayı hissederek yalnızlaşır ve toplumdan, toplumsal değerlerden kopmaya başlar. İnsanın varoluşu ile ilgili sorularında aklın yetersiz kalışı ve bireyin kendini hiçbir zaman anlayamayacağı bir dünyanın içinde bulması gerçeğiyle baş başa bırakır. Bu durum onun umuduna da ket vurur. Zamana etki edememesi karşısında çaresiz duruma düşer. Dolayısıyla aklı onu bu dünyaya aykırı hale getirir. Çünkü 'saçma' ancak bilincin varlığı ile mümkündür (Akış 2007: 120-121). 
İnsan, 'dekorların yıkıldığı' anda, fark ettiği bu monotonluğun iç sıkıntısı ve saçmanın farkına varmasıyla nihilizmin kıyılarına kadar varır. Bir anlam aramaya koyulduğunda 'saçma'nın bir diğer atağı olan zamanı duyumsamaya başlar. Bütün umutlarını, hayallerini ve arzularını geleceğe bağlasa da ölümü ona getirecek olan da yine zamandır. Camus, bunu bir tutarsızlık olarak görmektedir, çünkü ölümü getirecek olan insanın umutlarını bağlamış olduğu gelecektir (Akıș 2007: 37).

'Saçma' (absürd-uyumsuz), insanın bilinçli olarak, içinde bulunduğu dünyayı bilmek istemesi ve anlamaya çalışmasına giriştiği ancak bunun mümkün olmadığı bir yolcuğun sonucudur. Dünya ile insan arasındaki iletişimsizlikten doğan bir uyumsuzluk durumudur. Bunu Camus "insanla yaşamı, oyuncuyla dekoru arasındaki bu kopma uyumsuzluk duygusunun ta kendisidir" (2016: 21) şeklinde ifade eder. İnsanın, akıl sahibi bir varlık olarak yaşadığı bu dünyayı rasyonellikle açıklayamaması,' uyumsuz'u insanın bir sorunu haline getirir. İnsan yaşadığı müddetçe pek çok saçma durum ile karşılaşır ve bu duygu yoğunlaştığında insanı yaşamak ve ölmek arasında bir seçim yapmaya zorlar.

Intihar bir yanılmadır ifadesi ile bu konudaki tutumunu çok net belirten Camus, bunu absürdden kaçışın kolay bir yolu olarak izah eder. İnsanın, uyumsuz duygusu ile yüzleşmesi yaşantısının herhangi bir döneminde gerçekleşebilir ve basit bir duygu olmaktan çıkarak insanı intihara itebilir. Çünkü hayatın tekdüzeliğinin farkına varan insan için yaşamın tüm dekorları parçalanır ve insan bugünün, yarının ve geleceğin de aynı olacağ1 düşüncesinde intiharla karşı karşıya gelmekten kaçamaz. Ancak Camus'a göre insanın yaşam şartları ve konforu ne durumda olursa olsun insan uyumsuz ile yaşamayı öğrenmeli ve intihardan kaçınmalıdır. Çünkü intiharı tercih etmek uyumsuzu ortadan kaldırmak için gerçek bir çözüm değildir. Bunu şu ifadeleri ile daha net anlamaktayız:

"Yaşamak, uyumsuzu yaşamaktır. Uyumsuzu yaşatmak her şeyden önce ona bakmaktır. Uyumsuz ancak kendisine sirt çevrildiği zaman ölür. Böylece tutarl olan ender felsefe durumlarından biri başkaldırı olarak belirir" (Camus 2016: 67-68).

İnsanın iradesi dışında içine düştüğü bu karmaşa ve uyumsuz duygusu karşısında umut ya da intiharı çözümsüz gören Albert Camus, çareyi ancak 'başkaldırı'da bulur. "Zıtlıkların bir arada var olduğu gibi saçma ile de insan birlikte varolmuşlardır ve yaşamak için birbirlerine ihtiyaç duymaktadırlar" (Özdemir 2012: 27). Bu noktada Camus için olmas1 gereken uyumsuzu ortadan kaldırmak değil aksine onun varlığını kabul ederek ve bunu bilerek uyumsuza karşı başkaldırmaktır. Başkaldırıyı saçmaya karşı gerçekleştirilen bir meydan okuma olarak gösterir.

Camus Veba adlı romanında başkaldırı kavramını olay örgüsü içinde resmeder: "Veba sembolik olarak insanın acılarının, yalnızlığının ve yazgısının bir ifadesidir" (Akış 2007: 65). Vebaya yakalanan insanların çektiği acıları ve ölümü anlatırken tıpkı insanların var olmasının kendi iradesi dışında gerçekleşmesi gibi hastalığın ve salgının da insandan bağımsız olarak meydana gelmesi arasında bir bağlantı kurar. Uyumsuzun bilincine varan insanın saçmaya başkaldırarak yaşamaya devam etmesini savunduğu gibi Veba eserinde de insanın acıları ve kaderini kabullenerek salgına başkaldırması gerektiğinin altını çizer. Buradaki başkaldırı toplumsal bir direnişi örnekler çünkü veba tüm insanları etkileyen ortak bir felakettir. Ancak 
burada Camus'un vurguladığı önemli husus başkaldırının gerekliliğidir. "Ama, işin doğrusu, o anda, ă̆ustosun ortasina, veba herkesin üstüne çökmüştü. Böylece bireysel yazgl diye bir şey artık yoktu; veba ve herkesin paylaştığl duygulardan oluşmuş toplumsal bir tarih vardl. En önemli duygu ayrılık ve sürgündü, bir de bu duyguların içerdiği korku ve başkaldırı", (Camus 2013: 124).

Her insan biriciktir ve bilhassa bu yüzden onu genellemelere sıkıştırmamak gerekir. Dolayısıyla her birey kendine özgü olduğu için yaşama ve başına gelen olaylara verdiği tepkiler farklıdır. Hayatta insanın başına gelebilecek olaylar zinciri de geniş bir halkaya sahiptir ve bu durum insanın yaşayabileceği iyi ve kötü olayların çeşitliliğini arttırıyor demektir. İşte bu vaziyette iyi, orta halli veya idare edebilir düzeyde bir yaşam kalitesine ve uygun şartlara sahipsek Camus'nun savunduğu gibi başkaldırıp direnebilecek cesareti gösterebilmek zor olmayacaktır. Ancak her insan yaşadığı kötü durumlar karşısında da yaşamaya devam edebilme cesareti gösterebilecek kadar güçlü müdür?

Tüm bunlardan hareketle Camus'un söylemleri, bütün insanlık için yapılmış bir genellemeyi oluşturur yorumunda bulunabiliriz. İnsan dediğimiz varlık özgündür ve onu genellemelerle sınırlandırmaya, anlamlandırmaya çalışmak onun özgünlüğüne ters düşerek kolaya kaçmamıza neden olacaktır. Bu noktada bir hüküm vermek için daha dikkatli olmamız gerekir. Kanaatimizce Camus'nun görmeyi reddettiği ya da genellemesinden kaynaklanan eksik nokta, insanın psikolojik durumu ve o an içinde bulunduğu duygularıdır. Yaşam ve sorumluluk baskısıdır. İnsanı yaşantısından soğutan ve hissettiği duygu durumundan ayrı düşünmek bizi hataya sürükleyecektir.

Zaten bir noktada bütün insanların aynı olmadığını düşünürsek Camus'nun tüm insanlık için aynı genellemeyi yaparak, insanı tek tipleştirerek hataya düştüğünü söyleyebiliriz. Tüm insanlar ve hayatlar benzersiz ve özgün ise insan, saçmaya başkaldırmalıdır genellemesini yapmak hatalı olacaktır.

\section{Absürd}

Absürd kelimesi; saçma, tutarsız, akla uygun olmayan, mantıksız gibi anlamlara tekabül etmektedir. Olumsuz bir anlam taşıdığı görünse de Camus'un bu kelimeden olumlu bir anlam çıkarmaya çabaladığını söylemek mümkündür. $O$, dünyanın akla uygun olmadığı kanaatindedir. Absürd olarak nitelendirdiği kavram, dünya ile insan arasındaki tek bağlantıy oluşturur. Başka deyişle dünya ile aklın uyuşmazlığı, insanın dünyada cevap aradıklarını akıl ile bulamayışının yarattığı kırılmaya dikkat çeker:

"Ăgaçlar arasında bir ăgaç, hayvanlar arasında bir kedi olsaydım, bu yaşamın bir anlamı olurdu, daha doğrusu bu sorunun hiç anlamı olmazdl, çünkü dünyadan bir parça olurdum. Bu dünya olurdum, oysa şimdi tüm yakınlık gereksinimimle onun karşısındayım. Öylesine önemsiz olan bu us, işte beni tüm evrenin karşıtı yapan bu” (Camus 2016: 66). İnsan sahip olduğu akıl ile sorular sormaya başlar. İçinde bulunduğu dünyaya yönelerek kendine, yaşama ve başkalarına yönelttiği sorular ve aradığı cevaplar ile kendisinin farkına varır. Ancak bazı cevap bulamayışlar ve aklın yetersiz kalışı onu kendine ve dünyaya karşı yabancılaşmanın kaçınılmaz bir evresine doğru sürükler. 
İnsan, sosyal ve toplumsal bir bütünün parçasını oluşturur. Dolayısıyla yaşadığı, şahit olduğu, duyduğu şeylerden etkilenerek kendi dünyasını oluşturur ve bilinçli olarak yapmasa da bu durum düşüncelerinin oluşumunu da etki altında bırakır. Kişinin kendi dünyasının ve kendi dışındaki çevresel faktörlerin meydana getirdiği fikirlerin zaman zaman uyuşmaması da insanda yabancılaşma duygusunu hissettirmeye başlar. Camus bunu Yabancı romanında Meursault'nun kendisini savcının gözünden dinlemesiyle okuyucuya hissettirir: "Ruhumu mercek altına aldığın ve hiçbir şey bulamadığın söylüyordu, işte böyle sayın jüri üyeleri. Aslinda, bende ruhtan eser yokmuş insanliktan da, hatta insan kalbini esirgeyen ahlak kurallarının birine bile sahip değilmişim" (Camus 2016: 92).

Absürd (saçma), insanın, yaşadığı dünya ile yüzleşmesinde bir mana bulamayışının, insanın hayattan kopuşunun adıdır. Saçmanın ilk belirtisi, insanın hayatın monotonluğu karşısında kendini, diğer varlıkları ve yaşamı sorgulamasıdır. Saçma kavramı, insanı, zamanı değiştiremez oluşu ve ölümün kaçınılmaz gerçekliği ile yüzleştirdiğinde yaşantısına yabancılaşmasını ve yalnızlığı getirir. İnsanın ölüm karşısında mutlak güçsüzlüğü saçmanın ve yabancılaşmanın asıl zeminini oluşturur. "Camus felsefesinde diğer ateist varoluş̧̧ularda olduğu gibi Tanrı'nin varlığı kabul edilmediğinden, insan kendini bırakllmışlık ve anlamsızlık içinde bulur. Bunun sonucu ise uyumsuzla karşılaşmadır" (Akbulut 2014: 50).

Camus, yaşamın ancak ölüm ile birlikte anlaşılabileceğini düşünür. Çünkü aslında insanı uykusundan belki de hayattaki koşuşturmadan kaynaklanan dalgınlığından uyandıran budur. Absürd, insanın bilinçli olarak içinde bulunduğu dünyayı bilmek gayreti ve anlamaya çalışmasıyla ancak bunun mümkün olmadığı bir yolcuğun sonucudur: "Ölüm tek gerçek olarak durmaktadir önümde. Ondan sonra iş işten geçmiştir" (Camus 2016: 71).

Ölümün varlığı, insanın bu dünyada zamanının sınırlı olduğunu bilmesini sağlar. Haliyle yaşamına bir gaye katmak isteyen insan elini çabuk tutmalıdır. Çünkü hayatın bir bilgisayar oyunu gibi en başa dönmesi ya da tekrarı yoktur ölüm başlı başına gerçek bir sondur. Bu hissiyat insanı ölüm düşüncesinden ürkütür. İnsan yalnızca kendi ölümünden değil sevdiklerinin ölümünden de korkar. Çünkü ölüm varlığımızın sonu demektir. Zannımca insan, sevdiklerine karşı kurmuş olduğu duygu bağını yaşama karşı da kurmuş olduğu için ölüm düşüncesi ona korkutucu ve üzüntü verici gelmektedir. Camus, ölümün insanda farklı etkiler bıraktığına romanlarında da değinmiștir: "Belki de yaşamı yeterince sevmiyor muyuz? Duygularımızı yalnız ölümün uyandırdlğına dikkat ettiniz mi? Bizden yeni ayrılmış dostlarımızı ne kadar severiz değil mi? ağızları toprakla dolup hiç konuşmaz olmuş hocalarımıza ne kadar hayranizdir!" (Camus 1997: 26).

Heidegger, insanı ölümlü bir varlık olarak ele almaktan ziyade ölüm yönelimli bir varlık olarak ele alır. Ölümden kaçamayacak olan insanın her an ölümünün gerçekleşebilecek olması sebebiyle onu bir kaygı varlığı şeklinde görmesine neden olur çünkü kayg1 ölüm düşüncesi ile yakından iliş̧kilidir. İnsanın ölümlü olduğunu bilincinde olması bu yönünü başka birine devredemeyecek oluşu onda kaygı duygusu yaratır. "Öyleyse ölüm ölüme yönelik varlı̆ğn bizzat kendisinin üstlenmek zorunda olduğu bir imkândır" (Polat-Așkın 2017: 50).

Camus'nun yanı sıra Sartre da saçma kavramı üzerine felsefe yapan bir filozof olmuştur. Benzer felsefi kaygıları taşısalar da saçmaya yükledikleri anlamda farklılıklar 
olması aralarındaki kavganın nedenlerinden olmuştur. Sartre Camus'ya kıyasla fiziksel olana daha negatif bir yaklaşım sergileyerek Bulantı adlı eserinde duyduğu derin tiksintiyi anlatır. "Heidegger'in ölümü bir olanak olarak kabul eden düşüncesine tam bir karşıtllkla kendi ölüm düşüncesini kuran Sartre'a göre, ölüm tam anlamıyla absürttür. Dünyada olmanın nedensizliği gibi ölecek olmanın da bir nedeni yoktur" (Polat-Aşkın 2017: 52). Sartre bu nedenle ölümün saçma olduğu kanaatindedir. Ona göre ölüm denilen, insanda sadece bulantı duygusu oluşturan bir olgudur.

Camus için, absürd karşısında tek anlamlı olan yol başkaldırıdır. Başkaldırı, saçmanın bilincinde olarak ona karşı gelmekle mümkün olabilir. İnsanı gerçekliğinden koparmadan ve bilinci yok etmeden saçmaya karşı oluşturulabilecek en doğru tavır da bu sebeple başkaldırıdır. "intihar uyumsuzu kendince çözer. Onu da aynı ölüme sürükler. Ama biliyorum ki sürüp gitmek için uyumsuzun çözüme varmaması gerekir. Aynı zamanda hem bilinç hem de ölümün yadsınması olduğu ölçüde intihardan slyrılır (...) bu başkaldırı yaşama değerini verir” (Camus 2016: 68). Böylelikle Camus'nün felsefesindeki sorunlara karşıllk geliştirdiği çözümü başkaldırıda bulduğunu görmekteyiz. Bu husustan Başkaldıran İnsan adlı eserinde de

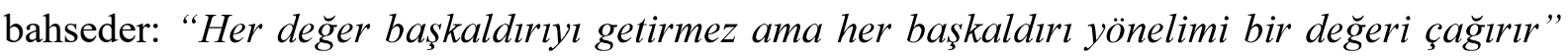
(Camus 1995: 11).

Camus, absürd durumu mitolojik kahraman Sisifos ile anlatır. Sisifos Söyleni adlı eserinde yer verdiği mitolojik kahraman Sisifos, Tanrıları kızdırarak bir cezaya çarptırılmıştır. Cezası, dinlenmeksizin bir kayayı dağın en tepesine çıkarmaktır. Kayayı tepeye çıkardıkça ağırlığından dolayı kaya tekrar aşağı düşer. Sisifos ise kayayı tekrar tepeye çıkarır. Kaya tekrar aşağıya yuvarlanınca Sisifos kayayı tekrar tepeye çıkarmak zorunda kalır. O, sonsuza kadar bu döngüyle cezalandırılmıştır.

Sisifos, dinlenmeden bin bir güçlükle dağın tepesine kayayı çıkarırken insanların durumunun bilincine varır. Yazgısını yani çarptırıldığı cezanın bilincine vararak aslında absürd olan bu cezaya rağmen kayayı, dolayısıyla yazgısını kabullenir. Çünkü kaya onun kayasıdır. Camus'nun da felsefesinde savunduğu buna benzeyen bir düşüncedir. İnsan, absürde rağmen hayata sarılmalıdır. Çünkü hayat ne kadar saçma ve anlamsız olursa olsun onun hayatıdır: "Sisifos'un tüm sessiz sevinci buradadır: yazgısı kendisinindir. Kayası kendi nesnesidir. Aynı biçimde, uyumsuz insan da sıkıntısı üzerinde gözleme başladı̆̆ zaman tüm putlart susturur" (Camus 2016: 140).

Nasıl bir hayata sahip olursak olalım, her şeyin anlamsız oluğunu söylesek bile anlamlı bir düşünce ortaya koymuş oluruz. Her şeyin anlamsız olduğunu söylemek tüm değer yargılarını yok etmek demektir. Anlamsız olduğu düşünülse dahi Camus, hayatın yaşanmaya değer olduğunu inatla savunmuştur.

Sebebini bilmediğimiz bir şekilde ve kendi irademizden bağımsız olarak dünyada var olduğumuzu belirtmek yanlış olmaz. İnsanın kendi iradesi dışında kendisiyle alakalı bir durumda bu şekilde kesin bir bilgiye sahip olmaması, onda kafa karışıklığı yaratır. Doğasında merak duygusuna sahip olan insan bunu tarih boyunca da sorgulayıp bir cevap aramaya girişmiştir. Ancak nesnel bir cevaba ulaşamaması da içinde yaşadığı bu dünya ile bir uyuşmazlık olmasına neden olmuştur. İnsan daima anlamak ve anlamlandırmak ister. Çünkü 
anlamak, bir şeyin sebebini bilmek insanda güven duygusunu yaratır. İçinde bulunduğu dünyayı kimi zaman anlayamamasının onda yarattığı huzursuzluk duygusu ise her şeyin saçma hayatın anlamsız olduğu kanaatine doğru düşünmeye sevk eder. İnsanın ölüm gerçekliğinden korkması da bu konunun bilgilerimiz dışında olmasındandır.

Ölümün her canlı için kaçınılmaz bir son olduğunu hepimiz biliyoruz ancak ölüm sonrasına dair bilgilerimiz yeterli kesinliğe sahip değildir. Haliyle insanı ölüm olgusundan korkutan da bu bilinmezliktir. İnsan bildiği gerçekliğe kendisini hazırlayabilir, buna uygun duygular ve kendini koruma mekanizması geliştirebilir ancak bilinmezlik hususunda durum böyle değildir. Dolayısıyla da insanın hem kendi ölümü konusunda hem de sevdiklerinin ölümü konusunda kaygı ve korku beslemesi kaçınılmazdır.

İnsan doğası gereği acıdan kaçınan bir varlıktır. Kaygı, korku ve haliyle ölüm de insana acı veren şeylerdir. Ölüm, nesnemiz olan bedenimizin yok olması demektir. Hâlbuki ahiret inancını düşündüğümüzde insan daima var olmak ister yorumunu yapabiliriz. Çünkü insan bedenen yok olduğunda yani öldüğünde bile aslında ruhen yaşamanın yani bir şekilde var olmanın çabasında olmuştur demek yanlış olmaz. Bu düşünceye dayanarak insanın içinde yaşama ve var olma arzusu olduğunu söyleyebiliriz. Ancak tabi ki düşünceler zamana, mekâna ve yaşantıya göre değişimler gösterebilir. Yani insan, yaşamayı seçebileceği gibi intiharı da seçebilir.

\section{İntihar}

İnsan yalnızca hayatı saçma bulduğu için ve bir anlam bulamadığı için mi intihara yönelir? İntihar olgusu gerçekten de yaşama verilen değeri ondan eksiltir mi? Acı içinde olan bir yaşam da mutlu bir yaşam kadar değerli midir? Pek çok karmaşık ve cevaplaması zor sorularla karşılaşabiliriz. İntihar olgusu, insanoğlunun yeryüzündeki varlığı kadar eski bir tarihe sahiptir. İntihar pek çok farklı kaynakta, kişinin kendi hayatına istemli olarak son vermesi şeklinde tanımlanmaktadır.

Camus Sisifos Söyleni eserinde intihar kavramına doğrudan değinir: "Gerçekten önemli olan bir tek felsefi sorun vardir, intihar. Yaşamın yaşanmaya değip değmediği konusunda bir yargiya varmak, felsefenin temel sorusuna yanit vermektir" (Camus 2016: 21).

Neden intihar etmiyorsunuz? Victor Frankl İnsanın Anlam Araylşı adlı eserine böyle çarpıcı bir girişle başlıyor. Hayatın anlamını, kendi yaşamak zorunda bırakıldığı hayattan ve gözlemlerinden yola çıkarak sorgulamaya ve cevap bulmaya çalışan Frankl, İkinci Dünya Savaşı sırasında toplama kampına götürülen bir psikiyatristtir. Anlam merkezli psikoterapi olan logoterapiyi oluşturmasında bu kampta yaşadıkları ve gördükleri etkili olmuştur. Frankl'ın düşüncesi, toplama kamplarında esir tutulan bunca insanın itibarını, yaşantısını, her şeyini kaybeden, tüm değerleri yıkılan, açlığın, sefaletin, işkencelerin altında ezilen ve her an gaz odalarında imha edilmeyi bekleyen ve hayatındaki tüm sevdiklerinin de bu şekilde öldürüldüğüne şahit olan insanların, niçin hala intihar etmediklerini onları yaşama bağlı tutan şeyin ne olduğunu anlamaya çalışmasıyla başlayan bir düşüncedir.

Albert Camus ise farklı bir pencereden bakarak umudu bir kötülük olarak yorumlar. Onu, Tanrıya ya da farklı bir hayata olan özlem olarak değerlendirir. Hayatta yaşanan tüm 
yanlışlıklara ve kötülüklere rağmen insanı ayakta tutmaya, direnmeye gayret ettiren şey umuttur. İnsan, saçmanın farkına vardığı an kendine anlam yükleyebileceği yeni bir hayat aramaya yönelir. Oysa Camus'nun savunduğu, insanın saçmayla yüzleşip onu kabul ederek, onunla birlikte yaşamayı öğrenmesidir. Umut ise insanın bu dünyadan kopuşunu, vazgeçişini dolayısıyla da saçmayı reddedişini gösterir.

Özellikle tanrı inancını reddeden insan, umut etmeden nasıl yaşar? İçinde yaşanılan şartlar ne kadar sancılı ve ürkütücü olursa olsun, insanın yaşam karşısında sorumlu olduğu duygusu onda nasıl uyandırılabilir? Acıya karşı dayanamayacak noktaya gelmiş ve her şeyden vazgeçmiş, acıyı sonlandırmak isteyen bir insanı intihardan geri döndürebilecek olan, insanı yaşama bağlayan nedir? Umut. Hayattaki tüm kötülüklere, anlamını arayıp da bulamadığımız yaşama ve dünyada olmaya, ancak bu şekilde katlanabiliriz, umutla avunarak. Geleceğimize, yarınımıza dair olmasını istediğimiz yönde daha iyisini umut ederek. Umut azalırsa psikolojik bunalımlar ortaya çıkar. Bunalımlar ise kaygıyı doğurur. Kaygı ise ölüm düşüncesiyle iç içe geçmiş bir zincir gibidir. Ölümün insana ne zaman geleceğinin belirsizliği insanda kaygıyı meydana getirir. Aslında buradan anlaşılacağı üzere bütün duygular iç içe geçmiş karmaşık yapılardan meydana gelir. İnsanın da bir duygu varlı̆̆ olduğunu unutmamak gerekir. $\mathrm{Bu}$ sebeple maddi olarak insan, duygusal ve manevi dünyasından ayrı düşünülemez ve parçalanamaz. Dolayısıyla intihar eylemini gerçekleştiren insanların hayatında ilk bakılması gereken nokta psikoloji ve içinde bulunduğu şartlar olmalıdır. Camus, bu fikre Sisifos Söyleni eserinde değinir:

"Bir intiharın pek çok nedeni vardır, genel olarak da en çok göze çarpanları en etkenleri olmamıştır. Insanın bir düşünce sonucu intihar ettiği enderdir. Bunalımı başlatan şeyi denetlemek hemen her zaman olanaksızdır" (Camus 2016: 23).

Yaşamadığımız bir olay hakkında empati kurmak çok güçtür. Çünkü empati kurarak daha önceden deneyimlediğimiz duyguları hayal edebilir, canlandırabiliriz. Ancak daha önce hiç yaşamadığımız bir hissin tasvirini yapabilmek neredeyse imkânsızdır. İnsanın hiç ölmeyecekmiş gibi yaşamasının sebebi de kendi ölümünün deneyimine sahip olmamasıdır. Dışarıdan gözlemleyip deneyimlemediğimiz durumlarda fikir beyan ederken ve bireyi intihara götüren nedenler hakkında düşünürken bunu da unutmamak gerekir. İnsanı intihara iten nedenleri ya da intiharı seçen insanları anlamaya çalışırken de bu özveriyle yaklaşabilmek elzemdir.

İntihar, hayatın anlamsızlığından ortaya çıkan saçma duygusuyla birlikte insanı ve bilinci de yok eder. Bu sebeple, intiharı saçmaya karşı yapılmış bir galibiyet olarak değil bir yenilgi ve vazgeçiş olarak görebiliriz. Camus, intiharı tercih etmek yerine hayata dört elle sarılmak gerektiğini savunur. Ölümlü olduğu gerçeğini bilen insanın yapması gereken, hayatını daha da dolu yaşamaktır. Ölüm, aslında yaşamayı değerli kılan en belirgin unsurdur. Camus, hayatın yaşanmaya değer olması için bir anlam belirlenmiş olmasına karşı çıkar. İnsan kendi amacını bulmalı ve kendini gerçekleştirmelidir. Oysa anlamı belirlenmiş bir dünyada insanın özgürlüğü hepten elinden alınacaktır. Onun asıl önemli gördüğü şey anlamın olmadığı bir dünyada, insanın bireysel ve özel hedefleriyle kendini gerçekleştirmesidir. 
İntiharı, bir kolaya kaçma olarak gören Camus, yaşamak için intihardan daha fazla cesarete ihtiyaç olduğunu dile getirir. Yani ölüm kolay olandır, zor olan saçmaya rağmen yaşamaktır. Ölümün, insan elinden çıkma her türlüsüne karşı durur. Cinayet, idam, intihar bunların hepsine aynı ölçüde karşı dururken birini diğerinden ayırmaz. İntihara başvurmak yaşamı yok etmek demektir. Yok etmek ise şiddete başvurmaktan geçer. Bu sebeple de yaratamayan insan yok etmeye yönelmiş olur. Yok etmek ise bahşedilen hayatı ortadan kaldırarak ondan öç almak anlamını çıkarmaya vesile olabilir.

İnsanın, insan içinde farklılaşmasından doğan öznellik, sorulara verilen yanıtların da beraberinde yepyeni sorular getirmesine neden olmaktadır. Bu sebeple belki de herkes kendi cevabını ve amacını bulur. İnsan yaşayarak, deneyimleyerek, öğrenerek var olur. Bir nevi bu şekilde hayata karışır ve kendi yolunu, kendisi olabilmenin imkânını arar. Ancak insanın karşısına elinde olmayan sebepler, olaylar ve durumlar da çıkar. İşte insanın iradesi de bu noktada kendi verdiği kararlar ile ortaya çıkar demek mümkündür.

\section{Sonuç}

Gerçekten bir Nazi kampına kapatılsaydınız, sevdiklerinizin acımasızca öldürülmelerine şahit olsaydınız ve oradan kurtulma ihtimalinin olmadığını bilerek tanrıya isyan etseydiniz ya da tanrıyı inkâr etseydiniz, intihara karşı durabilir ve hala yaşamayı seçebilir miydiniz? Hayatınızı çalmış olsalar, sevdiklerinizden gaddarca ayırmış olsalar, tüm benliğinizi yıkıp tahrip etmiş olsalar da yine de yaşamayı göze alabilir miydiniz? Bunlar çok ciddi empati gerektiren sorular. Çünkü bir olay başımıza gelmeden ne derece bizi etkileyebileceğini bilemeyiz. Ama asıl önemli olan umut olmadan bunların hiçbirine karşı koyamayacağımız gerçeğidir. Çünkü umut hayatın dinamitidir. İnsanı güdüleyen ve devam etme gayretini veren içindeki umut duygusudur. Bu duygu onu kamçllayarak mücadele ruhunu da arttıracaktır.

Umutsuz bir durumla karşılaştığımızda, değiştirilemeyecek bir kaderle yüz yüze geldiğimizde bile, yaşamda bir anlam bulabiliriz. Anlam istemi temel bir güdüdür. $\mathrm{Bu}$ anlam sadece kişinin kendisi tarafından bulunabilir, bu nedenle eşsiz ve özel bir yapıdadır. Ancak o zaman kişinin kendi anlam istemini doyuran bir önem kazanabilmektedir. Kişi yaşama amacını bulduğu takdirde onur kırıcı olan tüm davranışlara karşı kendi gelişimini sürdürebilir.

İnsan niçin acıya katlanır? Buna cevaben Tanrıya inanan insanlar, bu dünyanın bir sınav olduğu ve bu dünyadaki davranışlarıyla cenneti kazanabilme arzusu içinde olarak yaşadıklarını kabullenme cesareti gösterip saçmaya başkaldırabilirler. Cenneti kazanmayı ve orada huzur bulmayı umut ederek kendilerini yaşamaya motive edebilir, acıya katlanmayı bir imtihan olarak kabul görebilirler.

İnsan doğar, büyür ve ölür. Basit bir olgu gibi görünse de acımasız hakikat budur. İnsan, yaşam ve ölüm arasında göreceli olsa da aslında çok kısa olan bir zaman dilimine kendisini sığdırmaya çalışır. Kendisini bulmaya, amaçlarına ulaşmaya ve belki de duygusal olarak tatmin olmaya çalışır. Hayat ve ölümün bu aralığında illaki bir yaşam amacı bulmalı mıyız? İnsan bir amaç uğruna olmadan da yaşamını sürdürmeyi seçemez mi? Mevzubahis insan ise verilebilecek cevaplar da sınırlı değildir kuşkusuz. Çünkü insan dediğimiz varlık henüz tam olarak bilmecesi çözülmüş, tanıdığımız, bildiğimiz, sınırlandırabildiğimiz bir konu değil. 
Hayata bir anlam ararken, belki de anlamlı olan yaşamaktır. Çünkü her şeyi yok edecek olan ölüm, yaşama anlamını veren değerdir. Aslında her şeyi eşitleyen ölümdür. Tüm insanlara bahşedilmiş yaşamın ayrıcalıksız tüm canlılara sunduğu ve bu konuda herkesin eşit olduğu durum ölümdür. Ve ölüm yaşama dokunmadan evvel insan hayatının anlamını ya da amacını bulmak zorundadır.

İnsanın kendi iradesi ile ölümü seçmesine yani intihar düşüncesine karşı yaşam arzusuna duyduğumuz saygı kadar olgun davranamıyor olabilir miyiz? İnsan nasıl bir durumun içinde yaşarsa yaşasın mutlaka ölümden kaçınmalı yaşamaktan yana mı olmalıdır? Burada ağır basan akıl ile verilen cevap değil duygunun vermiş olduğu ağırlıktır kanaatimce. Çünkü insan yaşarken, karar verirken aklı kullandığından çok duyguları ile de farkında olmadan hareket eder. Her insanın duygu dünyası ve geliştirdiği hassasiyetler farklılıklarla doludur. Dolayısıyla insanların acı eşiği ve katlanabilme, dayanabilme gücü de çeşitlilik gösterir. Bu sebeple bireyselliği ön planda tutarak düşünecek olursak yaşam, ölüm ve intihar kavramlarını daha da ciddiye almamız gerekir.

O halde kendi tanıtlamamı şu şekilde yapabilirim; bir insanı insani olarak öldürmek onun elinden tüm umutlarının ve amacının alınmasıdır. Bir insanı yaşatmak ve hayata bağlamak istiyorsanız, ona tutunacağı bir umut ve bir amaç vermelisiniz. Gerisini hayat kendisi hediye edecektir.

\section{Kaynakça}

Akış, Yasemin (2007). Albert Camus Ve Jean Paul Sartre'da 'Saçma'nın Karşılaştırılması. Yüksek Lisans Tezi. Muğla: Muğla Üniversitesi, Sosyal Bilimler Enstitüsü.

Akbulut, Burcu (2014). Etik Bağlamda Albert Camus’nün Başkaldırı Felsefesi. Yüksek Lisans Tezi. Aydın: Adnan Menderes Üniversitesi, Sosyal Bilimler Enstitüsü.

Camus, Albert (1995). Başkaldıran İnsan. İstanbul: Can Yayınları.

Camus, Albert (1997). Düşüş. İstanbul: Can Yayınları.

Camus, Albert (2007). Yabancı. İstanbul: Can Yayınları.

Camus, Albert (2013). Veba. İstanbul: Can Yayınları.

Camus, Albert (2016). Sisifos Söyleni. İstanbul: Can Yayınları.

Frankl, Victor Emil (2017). İnsanın Anlam Arayışı. İstanbul: Okuyan Us Yayınları.

Özdemir, Öznur (2012). Albert Camus'nün Başkaldırı Felsefesinde Yabancılaşma Sorunu. Yüksek Lisans Tezi. Denizli: Pamukkale Üniversitesi, Sosyal Bilimler Enstitüsü.

Polat, Ezgi-Așkın, Zehragül (2017). "Ölüm Kavramının Heidegger Ve Sartre Felsefesindeki Yeri”. Kilikya Felsefe Dergisi (1): 44-52. 